\title{
Kinerja Keuangan dan Ukuran Perusahaan terhadap Harga Saham dengan Kebijakan Dividen sebagai Variabel Intervening
}

\section{Rico Wijaya Z}

Department of Management Faculty of Economics and Business Universitas Jambi Jl. Raya Jambi Ma.Bulian Km.15 Jambi, 36122, Indonesia

\begin{abstract}
Keywords:

Debt to Equity Ratio,

Dividend Payout

Ratio; Stock Prices;

Total Asset Turn-

over, Total Asset

JEL Classification: G02, G11, H54

Kata Kunci:

Debt to Equity Ratio,

Dividend Payout

Ratio; Harga

Saham; Total Asset

Turnover, Total

Asset

This was research conducted to examine the effect of the leverage ratio, activity ratio, and size firm on stock price with dividend policy as a mediating variable the companies listed in Indonesia Stock Exchange 2012-2014. This research has a total number of samples 141 samples and using purposive sampling with criteria declare a dividend payout for 3 consecutive years, and the debt to equity ratio, total asset turnover, which is positive. The first result is total asset turnover, Ln_total asset have positive effect on dividend payout ratio, and debt to equity don't have positive effect on dividend payout ratio. The second result is total asset turnover, Ln_total assets, and dividend payout ratio have positive effect on Ln_stock prices and debt to equity don't have positive effect on Ln_stock prices. Test results mediating dividend payout ratio is not provenmediates the relationship debt to equity, total asset turn over, and Ln_total asset on Ln_stock prices. The result of this research proves that there is no influence of dividend policy in relation of financial performance to stock price.

ABSTRAK

Penelitian ini dilakukan untuk menguji pengaruh rasio leverage, rasio aktivitas, dan ukuran terhadap harga saham perusahaan dengan kebijakan dividen sebagai variabel mediasi perusahaan yang terdaftar di Bursa Efek Indonesia 2012-2014. Penelitian ini memiliki jumlah total sampel 141 sampel dan menggunakan purposive sampling dengan kriteria menyatakan pembayaran dividen selama 3 tahun berturut-turut, debt to equity ratio, dan total asset turnover yang bernilai positif. Hasilnya pertama bahwa total asset turn over dan Ln_total aset berpengaruh positif terhadap dividend payout ratio, sedangkan debt to equity tidak berpengaruh positif terhadap dividend payout ratio. Hasil yang kedua bahwa total asset turn over, Ln_total aset, dan dividend payout ratio berpengaruh positif terhadap Ln_harga saham, sedangkan debt to equity tidak berpengaruh positif terhadap Ln_harga saham. Hasil uji efek mediasi menunjukkan bahwa dividend payout ratio tidak terbukti memediasi hubungan debt to equity, total asset turn over, dan Ln_total aset terhadap Ln_harga saham. Hasil penelitian ini terbukti bahwa tidak ada pengaruh kebijakan dividen dalam hubungan kinerja keuangan terhadap harga saham.
\end{abstract}




\section{Jurnal Keuangan dan Perbankan | KEUANGAN}

Vol. 21, No. 3, Juli 2017: 459-472

Pasar modal merupakan sarana terbaik untuk memobilisasi modal dan sekaligus membuat perusahaan menjadi lebih profesional. Untuk memahami proses investasi, seorang investor terlebih dahulu harus mengetahui beberapa konsep dasar investasi yang akan menjadi dasar pijakan dalam setiap tahap pembuatan keputusan investasi yang akan dibuat (Darmadji \& Fakhruddin, 2011). Perkembangan pasar modal tanah air sedang mengalami perbaikan, salah satunya penerapan ketentuan disclosure di Indonesia lebih baik dibandingkan negara lain (ekbis.sindonews.com).

Keputusan investasi di pasar modal tidak terlepas dari penilaian kinerja perusahaan. Kinerja keuangan merupakan salah satu cara dalam menentukan keputusan investasi di pasar modal. Para investor secara umum akan memilih perusahaan yang memiliki kinerja keuangan yang baik. Semakin baik kinerja keuangan suatu perusahaan, diharapkan akan mengikatnya harga saham di pasar modal (Al-Tamimi \& Kalli, 2009).

Pencapaian kinerja perusahaan tidak terlepas dari teori agency. Hubungan utama agency dalam bisnis adalah mereka (antara pemegang saham dan manajer) dan antara debtholders dan pemegang saham. Hubungan ini tidak selalu harmonis, memang teori keagenan berkaitan dengan konflik agency, atau konflik kepentingan antara agen dan pelaku. Oleh karena itu, teori keagenan telah muncul sebagai model yang dominan dalam literatur ekonomi keuangan dan secara luas dibahas dalam konteks etika bisnis (Jensen \& Meckling, 1976; Anthony \& Govindarajan, 2005).

Harga saham merupakan harga yang dibentuk dari interaksi para penjual dan pembeli saham yang dilatarbelakangi oleh harapan terhadap profit perusahaan. Kondisi permintaan atau penawaran atas saham yang fluktuatif tiap harinya akan membawa pola harga saham yang fluktuatif juga (Saptadi, 2007). Selisih antara harga beli dengan harga jual saham merupakan keuntungan yang dinikmati investor atas investasi saham yang dilakukannya (Hartono, 2008).
Untuk mengurangi risiko cara termudah adalah membuat portofolio investasi. Tujuan dari cara ini adalah mengurangi kerugian investasi yang mungkin timbul dari suatu sarana investasi dengan menutupnya menggunakan keuntungan yang diperoleh dari sarana investasi yang lain (Hadi, 2015). Selain menggunakan portofolio dalam berinvestasi di pasar modal, rasio keuangan juga dapat membantu menganalisa kinerja keuangan dalam membuat keputusan di pasar modal.

Kinerja keuangan merupakan suatu analisis yang dilakukan untuk melihat sejauh mana suatu perusahaan telah melaksanakan dan menggunakan aturan-aturan pelaksanaan keuangan secara baik dan benar (Keown et al., 2008; Mulyadi, 2010). Kinerja keuangan dapat dinilai dari beberapa rasio di antaranya rasio likuiditas, rasio aktivitas, rasio leverage, rasio profitabilitas, dan rasio pasar (Sutrisno, 2009).

Berikut ini penelitian yang berhubungan antara kinerja keuangan perusahaan dan harga saham yang dilakukan oleh Abdullah et al. (2015), hasilnya menunjukkan bahwa kinerja keuangan perusahaan berpengaruh negatif terhadap harga saham. Sedangkan penelitian yang dilakukan oleh Rakasetya, Darminto, \& Dzulkitrom (2013) serta Tan \& Syarif (2014), hasilnya menyatakan bahwa kinerja keuangan perusahaan berpengaruh positif terhadap harga saham. Kinerja keuangan yang baik akan menciptakan reputasi yang bagus, sehingga akan meningkatkan harga saham perusahaan.

Selain kinerja keuangan, ukuran perusahaan dapat memengaruhi harga saham di pasar modal. Ukuran perusahaan adalah cerminan besar kecilnya perusahaan yang berhubungan dengan peluang dan kemampuan untuk masuk ke pasar modal dan jenis pembiayaan eksternal lainnya yang menunjukkan kemampuan meminjam perusahaan. Berikut ini beberapa penelitian tentang pengaruh ukuran perusahaan terhadap harga saham yang dilakukan oleh Gunarso (2014) dan Murniati (2016), hasilnya ditemukan bahwa ukuran perusahaan berpengaruh 
positif terhadap harga saham. Sedangkan penelitian yang dilakukan oleh Rahmandia (2013), hasil menunjukkan bahwa ukuran perusahaan berpengaruh positif tidak signifikan terhadap harga saham. Artinya besar atau kecilnya ukuran suatu perusahaan berpengaruh terhadap pergerakan harga saham, tetapi tidak mampu untuk meningkatkan harga saham.

Guna menyeimbangkan keuntungan para investor, manajemen Bursa Efek Indonesia (BEI) saat ini tengah membahas aturan terkait pembagian dividen selain dari capital gain yang didapat selama ini (ekbis.sindonews.com). Pemegang saham mengharapkan return dalam bentuk dividen dan capital gains perusahaan. Disamping menginginkan pertumbuhan bisnis secara terus menerus, juga harus memperhatikan kemakmuran pemegang saham. Kebijakan dividen dapat dianalogikan sebagai puzzle yang berkelanjutan, dimana kebijakan dividen merupakan suatu teka-teki yang sulit dan dilematis untuk diputuskan oleh pihak manajemen perusahaan (Black, 1976).

Kebijakan dividen tidak terlepas dari teori signaling. Teori signaling menekankan kepada pentingnya informasi yang dikeluarkan oleh perusahaan terhadap keputusan investasi untuk pihak di luar perusahaan. Informasi merupakan unsur penting bagi investor dan pelaku bisnis karena informasi pada hakekatnya menyajikan keterangan, catatan atau gambaran baik untuk keadaan masa lalu, saat ini maupun keadaan masa yang akan datang bagi kelangsungan hidup suatu perusahaan dan bagaimana pasaran efeknya (Ross, 1977). Hubungan antara harga saham dan pengumuman dividen tergantung pada banyaknya informasi yang tergantung dalam pengumuman tersebut dan beberapa informasi yang terkandung dalam pengumuman tersebut dan banyaknya informasi memengaruhi ekspektasi investor (Gordon, 1959).

Penelitian tentang pengaruh kinerja keuangan perusahaan terhadap kebijakan dividen yang dilakukan oleh Kadir (2010) dan Sumiadji (2011), hasilnya menunjukkan bahwa kinerja keuangan perusahaan berpengaruh positif terhadap kebijakan dividen. Sedangkan penelitian yang dilakukan oleh Asif, Rasool, \& Kamal (2011) hasilnya menyatakan kinerja keuangan perusahaan berpengaruh negatif terhadap kebijakan dividen, artinya tidak adanya hubungan antara kinerja keuangan terhadap keputusan pemberian dividen oleh perusahaan.

Ukuran perusahaan (firm size) dapat diartikan sebagai besar kecilnya perusahaan dapat dilihat dari nilai equity, nilai perusahaan, ataupun hasil nilai aset dari suatu perusahaan (Riyanto, 2011). Penelitian tentang ukuran perusahaan terhadap kebijakan dividen pernah dilakukan oleh Dewi (2008), hasilnya menunjukkan bahwa ukuran perusahaan berpengaruh positif terhadap kebijakan dividen. Sedangkan penelitian yang dilakukan oleh Prawira, Dzulkirom, \& Endang (2014) hasil penelitiannya menunjukkan bahwa ukuran perusahaan berpengaruh negatif terhadap kebijakan dividen.

\section{PENGEMBANGAN HIPOTESIS}

Salah satu penilaian kinerja keuangan, dapat dilihat dari kinerja leverage perusahaan, dimana rasio leverage digunakan untuk mengukur sejauh mana aset perusahaan dibiayai dengan utang. Artinya adalah besarnya jumlah utang yang digunakan perusahaan untuk membiayai kegiatan usahanya jika dibandingkan dengan menggunakan modal sendiri. Agar perbandingan penggunaan kedua rasio ini dapat terlihat jelas, kita dapat menggunakan rasio leverage (Sutrisno, 2009).

Pada perseroan terbatas, pembagian keuntungan kepada pemilik dilakukan melalui dividen. Dividen hanya dapat dibayarkan jika saldo laba ditahan positif. Jadi walaupun dalam tahun berjalan diperoleh laba, suatu perseroan terbatas tidak boleh membagikan dividen jika saldo laba ditahan pada akhir tahun masih negatif. Pemberian dividen oleh perusahaan diharapkan dapat memberikan 


\section{Jurnal Keuangan dan Perbankan | KEUANGAN}

Vol. 21, No. 3, Juli 2017: 459-472

reputasi yang baik di mata investor dan calon investor, sehingga akan berdampak positif terhadap kinerja keuangan perusahaan (Radoni \& Ali, 2014).

Penelitian tentang pengaruh leverage perusahaan terhadap kebijakan dividen yang dilakukan oleh Sumiadji (2011) dan Awad (2015) hasilnya menunjukkan bahwa leverage perusahaan berpengaruh positif terhadap kebijakan dividen. Besar atau kecilnya rasio leverage perusahaan akan memengaruhi kebijakan dividen perusahaan. Berdasarkan pernyataan tersebut dapat dirumuskan hipotesis pertama sebagai berikut:

$\mathrm{H}_{1}$ : rasio leverage perusahaan berpengaruh positif terhadap kebijakan dividen

Penilaian kinerja keuangan dapat juga dinilai dari segi aktivitas perusahaan. Rasio aktivitas merupakan rasio yang digunakan untuk mengukur tingkat efisiensi pemanfaatan sumber daya perusahaan (penjualan, sediaan, penagihan piutang, dan lainnya) atau rasio untuk menilai kemampuan perusahaan dalam melaksanakan aktivitas seharihari. Dari hasil pengukuran dengan rasio ini akan terlihat apakah perusahan lebih efisien atau sebaliknya dalam mengelola aset yang dimilikinya (Kasmir, 2011). Tingginya keuntungan perusahaan merupakan salah satu signal pemberian dividen oleh perusahaan (Riyanto, 2011).

Penelitian tentang rasio aktivitas perusahaan terhadap kebijakan dividen pernah dilakukan oleh Hanim, Dzulkirom, \& Topowijono (2015) serta Rahmawati, Saerang, \& Rate (2014) hasilnya menunjukkan bahwa rasio aktivitas perusahaan berpengaruh positif terhadap kebijakan dividen. Tingginya aktivitas perusahaan yang pencapaian keuntungan perusahaan merupakan gambaran kemakmuran perusahaan sehingga dimungkinkan perusahaan akan membagikan dividen, oleh karena itu dapat dirumuskan hipotesis kedua sebagai berikut:

$\mathrm{H}_{2}$ : rasio aktivitas perusahaan berpengaruh positif terhadap kebijakan dividen
Hartono (2008) mengatakan bahwa ukuran perusahaan dapat ditentukan berdasarkan total aset perusahaan sesuai laporan keuangan terakhir perusahaan. Bagi perusahaan yang memiliki total aset yang besar menunjukkan bahwa perusahaan tersebut telah mencapai tahap kedewasaan (maturity). Sehingga aliran kas positif karena tidak banyak kebutuhan dana untuk investasi dan dianggap memiliki prospek yang baik dalam jangka waktu relatif lama. Kondisi ini akan menguntungkan para pemegang saham dalam hal pembagian dividen. Ukuran perusahaan sering dilihat dari sisi besarnya total aset, dimana dengan besarnya total aset perusahaan dapat mencerminkan posisi kedudukan perusahaan dimana investor dan calon investor lebih menyukai perusahaan dengan tingkat total aset yang tinggi atau besar.

Beberapa penelitian terdahulu tentang ukuran perusahaan terhadap kebijakan dividen dilakukan oleh Kardianah \& Soedjono (2013) dan Khan et al. (2013) hasilnya menunjukkan bahwa ukuran perusahaan berpengaruh positif terhadap kebijakan dividen. Besarnya ukuran suatu perusahaan diharapkan, akan selalu memberikan dividen perusahaan kepada para pemegang saham, maka hipotesis ketiga dapat dirumuskan sebagai berikut:

$\mathrm{H}_{3}$ : ukuran perusahaan berpengaruh positif terhadap kebijakan dividen

Rasio leverage biasanya dipergunakan untuk menggambarkan kemampuan perusahaan untuk menggunakan aset atau dana yang mempunyai beban tetap (fixed cost assets or funds) untuk memperbesar tingkat penghasilan (return) bagi pemilik perusahaan (Syamsuddin, 2009). Perusahaan yang dapat mengelola leverage perusahaan secara baik dapat diasumsikan bahwa pihak manajemen perusahaan berjalan efektif dan efisien.

Penelitian yang berhubungan antara rasio leverage perusahaan dan harga saham pernah dilakukan oleh Kohansal et al. (2013) serta Ullah \& Shah 
(2014), hasilnya menyatakan bahwa rasio leverage perusahaan berpengaruh positif terhadap harga saham. Semakin efektif pihak manajemen perusahaan mengelola leverage, maka semakin baik reputasi perusahaan, sehingga akan menaikkan harga saham. Atas dasar uraian tersebut, maka hipotesis keempat dirumuskan sebagai berikut:

$\mathrm{H}_{4}$ : rasio leverage perusahaan berpengaruh positif terhadap harga saham

Rasio aktivitas adalah rasio yang mengukur seberapa efektif perusahaan dalam memanfaatkan semua sumber daya yang ada padanya. Perhitungan rasio aktivitas melibatkan perbandingan antara tingkat penjualan dan investasi pada berbagai jenis aset (Harmono, 2011). Menurut Tandelilin (2010) menyatakan bahwa return saham adalah salah satu faktor yang memotivasi investor berinvestasi dan juga merupakan imbalan atas keberanian investor untuk menanggung risiko atas investasi yang dilakukannya.

Beberapa penelitian terdahulu tentang pengaruh rasio aktivitas perusahaan terhadap harga saham yang dilakukan oleh Martani, Mulyono, \& Khairurizka (2009) serta Khotimah \& Murtaqi (2015) hasilnya menunjukkan bahwa rasio aktivitas perusahaan berpengaruh positif terhadap harga saham. Tingginya tingkat rasio aktivitas perusahaan mencerminkan bahwa perusahaan dalam kondisi baik, sehingga dapat meningkatkan harga saham. Oleh karena itu, hipotesis kelima dirumuskan sebagai berikut:

$\mathrm{H}_{5}$ : rasio aktivitas perusahaan berpengaruh positif terhadap harga saham

Ukuran perusahaan adalah skala besar kecilnya perusahaan, suatu perusahaan besar yang sudah mapan akan memiliki akses yang mudah menuju pasar modal. Kemudahan tersebut cukup berarti untuk fleksibilitas dan kemampuannya untuk memperoleh dana yang lebih besar, se- hingga perusahaan mampu memiliki risiko pembayaran dividen yang lebih tinggi daripada perusahaan kecil. Jadi semakin besar ukuran perusahaan maka dividen yang dibagikan juga semakin besar (Saptadi, 2007).

Beberapa penelitian tentang pengaruh ukuran perusahaan terhadap harga saham yang dilakukan oleh Acheampong, Agalega, \& Shibu (2014) serta Murniati (2016), hasilnya menemukan bahwa ukuran perusahaan berpengaruh positif terhadap harga saham. Semakin besar suatu perusahaan merupakan reputasi yang baik dalam perusahaan, sehingga diharapkan akan meningkatkan harga saham perusahaan. Berdasarkan pendapat tersebut, maka hipotesis keenam dirumuskan sebagai berikut:

$\mathrm{H}_{6}$ : ukuran perusahaan berpengaruh positif terhadap harga saham

Dividen merupakan pembagian keuntungan yang diberikan perusahaan dan berasal dari keuntungan yang dihasilkan perusahaan. Dividen diberikan setelah mendapat persetujuan dari pemegang saham dalam RUPS. Jika seorang pemodal ingin mendapatkan dividen, maka pemodal tersebut harus memegang saham tersebut dalam kurun waktu yang relatif lama, yaitu hingga kepemilikan saham tersebut berada dalam periode dimana diakui sebagai pemegang saham yang berhak mendapatkan dividen. Dividen yang dibagikan perusahaan dapat berupa dividen tunai, artinya kepada setiap pemegang saham diberikan dividen berupa uang tunai dalam jumlah rupiah tertentu untuk setiap saham (Fahmi, 2012). Keputusan pemberian dividen oleh perusahaan merupakan reputasi yang baik, sehingga dapat meningkatkan harga saham perusahaan.

Penelitian tentang kebijakan dividen terhadap harga saham antara lain dilakukan oleh Hunjra et al. (2014) serta Ullah, Saqib, \& Usman (2015), hasilnya menyatakan bahwa kebijakan 


\section{Jurnal Keuangan dan Perbankan | KEUANGAN}

Vol. 21, No. 3, Juli 2017: 459- 472

dividen berpengaruh positif terhadap harga saham. Keputusan pemberian dividen merupakan sinyal yang baik yang dikeluarkan oleh perusahaan, sehingga dapat meningkatkan harga saham perusahaan, oleh karena itu hipotesis ketujuh adalah sebagai berikut:

$\mathrm{H}_{7}$ : kebijakan dividen berpengaruh positif terhadap harga saham

\section{METODE}

Penelitian yang dilakukan adalah desain kausal, yaitu untuk menganalisis hubungan-hubungan antara variabel debt to equity ratio, total assets turnover, ukuran perusahaan, dividend payout ratio, dan harga saham melalui pengujian hipotesis. Sampel dalam penelitian ini adalah 47 perusahaan dari 517 perusahaan selama 3 tahun, yang terdaftar

Tabel 1. Penarikan Sampel Penelitian

\begin{tabular}{|c|c|c|c|}
\hline Uraian & 2012 & 2013 & 2014 \\
\hline Daftar Perusahaan yang terdaftar di Bursa Efek Indonesia. (sumber ICMD 2015) & 511 & 511 & 511 \\
\hline Perusahaan yang tidak memberikan dividen (Dividend Payout) & $(342)$ & (390) & $(380)$ \\
\hline Perusahaan yang memberikan Dividen & 169 & 121 & 131 \\
\hline Peruhahaan yang tidak memberikan dividen secara berturut-turut & $(110)$ & (62) & (72) \\
\hline $\begin{array}{l}\text { Perusahaan yang memberikan dividen secara berturut-turut selama periode penelitian } \\
\text { ( } 3 \text { tahun) }\end{array}$ & 59 & 59 & 59 \\
\hline Perusahaan bidang financial (keuangan) yang tidak termasuk dalam penarikan sampel & $(10)$ & (10) & (10) \\
\hline Perusahaan yang informasinya tidak lengkap & $(2)$ & $(2)$ & (2) \\
\hline Jumlah perusahaan yang menjadi sampel dalam penelitian & 47 & 47 & 47 \\
\hline
\end{tabular}

Tabel 2. Definisi Operasional

\begin{tabular}{|c|c|c|}
\hline Variabel & Definisi Operasional & Pengukuran \\
\hline \multirow[t]{3}{*}{$\begin{array}{l}\text { Variabel } \\
\text { Independen }\end{array}$} & $\begin{array}{l}\text { Debt to equity ratio (DER) merupakan imbangan antara } \\
\text { hutang yang dimiliki perusahaan dengan modal sendiri. } \\
\text { Semakin tinggi rasio ini berarti modal sendiri semakin } \\
\text { sedikit dibanding dengan hutangnya }\end{array}$ & $\begin{array}{l}\mathrm{DER}=\frac{\text { Total Hutang }}{\text { Modal }} \\
\text { Debt to equity ratio diukur dalam kali. } \\
\text { (Kasmir, 2011) }\end{array}$ \\
\hline & $\begin{array}{l}\text { Total assets turn over (TATO) merupakan ukuran } \\
\text { efektivitas pemanfaatan aset dalam menghasilkan } \\
\text { penjualan. Semakin besar perputaran aset semakin } \\
\text { efektif perusahaan mengelola asetnya. }\end{array}$ & $\begin{array}{l}\text { TATO }=\frac{\text { Penjualan }}{\text { Total Aset }} \\
\text { Total assets turn over (TATO) diukur dalam } \\
\text { kali (Sutrisno, 2009) }\end{array}$ \\
\hline & $\begin{array}{l}\text { Ukuran perusahaan (Size) adalah suatu skala dimana } \\
\text { dapat diklasifikasikan besar kecilnya perusahaan } \\
\text { menurut berbagai cara, antara lain total aset, penjualan, } \\
\text { log size, nilai pasar saham, kapitalisasi pasar, dan lain- } \\
\text { lain yang semuanya berkorelasi tinggi. }\end{array}$ & $\begin{array}{l}\text { Size }=\text { Log Total Asset (Ln_Total Asset) } \\
\text { Diukur dengan satuan desimal } \\
\text { (Panjaitan dkk., 2004). }\end{array}$ \\
\hline $\begin{array}{l}\text { Variabel } \\
\text { Mediasi } \\
\text { (Intervening) }\end{array}$ & $\begin{array}{l}\text { Dividend payout ratio (DPR) adalah merupakan rasio } \\
\text { antara dividen per lembar saham terhadap laba per } \\
\text { lembar saham, dalam persentase. }\end{array}$ & $\begin{array}{l}\mathrm{DPR}=\frac{\text { Divident per share } \times 100 \%}{\text { Earning per share }} \\
\text { Diukur dalam persentase }(\%) \\
\text { (Istanti, 2013) }\end{array}$ \\
\hline $\begin{array}{l}\text { Variabel } \\
\text { Dependen }\end{array}$ & $\begin{array}{l}\text { Variabel dependen dalam penelitian ini adalah closing } \\
\text { price (harga saham penutupan). Closing price adalah } \\
\text { harga yang diminta oleh penjual atau harga } \\
\text { perdagangan terakhir untuk suatu periode. }\end{array}$ & $\begin{array}{l}\text { HS= Logaritma }(\mathrm{Ln}) \text { Closing price } \\
\text { (Ln_Harga Saham) } \\
\text { (Ginting \& Suriany, 2013) }\end{array}$ \\
\hline
\end{tabular}


di BEI pada tahun 2012-2014, penarikan sampel penelitian dapat dilihat dari Tabel 1.

Penelitian ini menggunakan metode purposive sampling dengan kriteria memberikan dividend payout selama 3 tahun berturut-turut, serta debt to equity ratio dan total assets turn over yang bernilai positif, sehingga total jumlah sampel sebanyak 141 sampel. Teknik pengolahan data dilakukan dengan menggunakan program aplikasi WarpPLS Versi 5. Data yang digunakan dalam penelitian ini bersumber dari Indonesian Capital Market Directory (ICMD) tahun 2015 dan akses ke idx.go.id.

Untuk menguji hipotesis yang diajukan, variabel yang diteliti dalam penelitian ini diklasifikasikan menjadi variabel dependen, variabel independen, dan variabel mediasi. Variabel-variabel yang digunakan dalam penelitian ini disajikan pada Tabel 2.

Penelitian ini menggunakan metode partial least square (PLS). Evaluasi dalam PLS meliputi evaluasi inner model atau model structural. Analisa model struktural dapat dilakukan dengan mengevaluasi hasil estimasi parameter koefisien path dan tingkat signifikansinya. Persamaan inner model dalam penelitian ini adalah:

$\eta_{1}=\gamma_{1} \xi_{1}+\gamma_{2} \xi_{2}+\gamma_{3} \xi_{3}+\zeta_{1}$ Persamaan 1

\section{Keterangan:}

$\eta_{1} \quad=$ divident payout ratio (DPR)

$\xi_{1} \quad=$ debt to equity ratio (DER)

$\xi_{2} \quad=$ total assets turn over (TATO)

$\xi_{3} \quad=$ Ln_ukuran perusahaan (Size)

$\gamma_{1}, \gamma_{2,} \gamma_{3}=$ hubungan langsung variabel eksogen terhadap variabel endogen

$\mathrm{z}_{1} \quad=$ kesalahan dalam persamaan 1

$\eta_{2}=\gamma_{3} \xi_{1}+\gamma_{4} \xi_{2}+\gamma_{5} \xi_{3}+\beta_{1} \eta_{1}+\zeta_{2 \ldots \ldots \ldots \ldots . . .}$ Persamaan 2

Keterangan:

$\eta_{2} \quad=$ Ln_harga saham

$\xi_{1} \quad=$ debt to equity ratio (DER)

$$
\begin{aligned}
& \xi_{2} \quad=\text { total assets turn over (TATO) } \\
& \xi_{3} \quad=\text { Ln_ukuran perusahaan (Size) } \\
& \eta_{1} \quad=\text { dividend payout ratio (DPR) } \\
& \beta_{1} \quad=\text { hubungan langsung variabel endogen } \\
& \text { terhadap variabel endogen } \\
& \gamma_{3}, \gamma_{4}, \gamma_{5}=\text { hubungan langsung variabel eksogen } \\
& \text { terhadap variabel endogen } \\
& \zeta_{2}=\text { kesalahan dalam persamaan } 2
\end{aligned}
$$

$\mathrm{h}$ adalah vektor variabel observed endogen (dependen) dan $\xi$ adalah vektor variabel observeb eksogen (independen), $\zeta$ merupakan vektor residual, $\gamma$ dan $\beta$ adalah matrik koefisien jalur (path coefficient).

Secara keseluruhan kebaikan suatu model atau interpretasi dari model fit bertujuan untuk melihat sejauh mana bangunan model dalam rancangan penelitian ini dibangun, adapun hasil interpretasi dari model fit dapat dilihat dari Tabel 3.

Secara keseluruhan dapat dilihat dari Tabel 3 bahwa dari seluruh kriteria terpenuhi, walaupun terdapat beberapa kriteria yang memiliki hubungan yang lemah. Hasil average adjusted R-squared, average $\mathrm{R}$-squared, dan average adjusted $\mathrm{R}$-squared secara keseluruhan bersifat lemah. Artinya model analisis jalur yang dibangun bersifat lemah antara hubungan antar variabel. Perhitungan average block dan average full collinearity secara keseluruhan memiliki nilai di bawah ambang batas (cut of value) sebesar d" 5. Artinya model yang dibangun bersifat fit model atau dengan kata lain model yang dibangun tidak terjadi multikolinearitas. Hasil tenenhaus GoF sebesar 0,573, dapat dikatakan kekuatan prediksi model yang dibangun dalam memprediksi hubungan antar variabel (jalur yang dibangun) dalam penelitian ini bersifat besar atau kuat. Nilai simpson sparadox ratio sebesar 1,00, artinya model yang dibangun bebas simpsons paradox atau tidak adanya masalah kausalitas dalam penelitian. Sedangkan R-squared contribution ratio bernilai 1,00, artinya tidak ada kontribusi R-squared 


\section{Jurnal Keuangan dan Perbankan | KEUANGAN}

Vol. 21, No. 3, Juli 2017: 459-472

negative dalam penelitian ini. Serta nilai statistical suppression ratio sebesar 0,857 dapat diartikan bahwa model dalam penelitian ini bebas dari statistical suppression. Hasil dari uji signifikan hubungan antar path dapat dilihat pada Gambar 1.

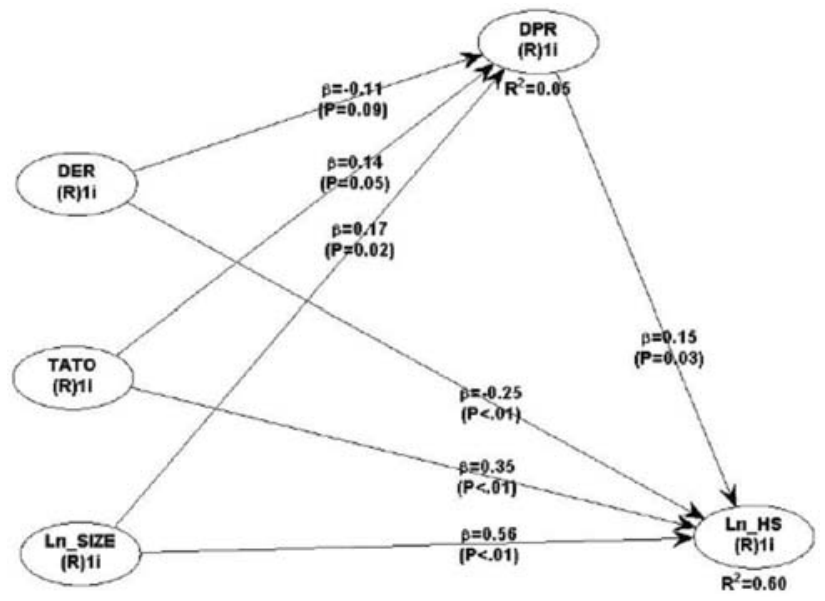

Gambar 1. Full Model

Sumber: ICMD data diolah
Berdasarkan Gambar 1, nilai R-squared yang dihasilkan variabel dependen Ln_HS sebesar 0,60, berarti bahwa variabel debt to equity ratio, total assets turn over, ukuran perusahaan, dan dividend payout ratio memiliki pengaruh sebesar $60 \%$ terhadap harga saham dan $40 \%$ dipengaruhi variabel lainnya. Artinya dapat disimpulkan model yang dibangun besifat moderat. Besaran nilai R-squared yang dihasilkan variabel dependen DPR sebesar 0,05 berarti bahwa variabel debt to equity ratio, total assets turn over, dan ukuran perusahaan memiliki pengaruh yang sangat kecil yaitu sebesar 5\% terhadap DPR dan 95\% dipengaruhi oleh variabel lainnya. Dapat disimpulkan bahwa model yang dibangun bersifat lemah.

Hasil evaluasi hipotesis berdasarkan model struktural yang dibangun, dilakukan dengan melihat nilai signifikan P-value, nilai signifikan yang digunakan dengan nilai P-value 0,10 (significance level $=10 \%), 0,05$ (significance level $=5 \%)$, dan 0,01

Tabel 3. Hasil Interpretasi dari Model Fit

\begin{tabular}{llcc}
\hline \multicolumn{1}{c}{ Kriteria } & \multicolumn{1}{c}{ Cut of Value } & Hasil & Evaluasi \\
\hline $\begin{array}{l}\text { Average path coefficient (APC) } \\
\text { Average }\end{array}$ & P-value $\leq 0,05$ & 0,248 & Lemah \\
R squared (ARS) & P-value $\leq 0,05$ & 0,329 & Lemah \\
Average adjusted $R$-squared (AARS) & P-value $\leq 0,05$ & 0,312 & Lemah \\
Average block VIF (AVIF) & $\leq 3,3$, namun nilai $\leq 5$ masih dapat diterima & 1,047 & Fit Model \\
Average full collinearity VIF (AFVIF) & $\leq 3,3$, namun nilai $\leq 5$ masih dapat diterima & 1,067 & Fit Model \\
Tenenhaus GoF (GoF) & $\geq 0,10, \geq 0,25$, dan $\geq 0,36$ (kecil, menegah, dan besar) & 0,573 & Besar \\
Sympson sparadox ratio (SPR) & Idealnya $=1$ namun nilai $\geq 0,7$ masih dapat diterima & 1,000 & Fit Model \\
R-squaredcontributionratio (RSCR) & Idealnya $=0,9-1$ namun nilai $\geq 0,7$ masih dapat diterima & 1,000 & Fit Model \\
Statistical suppression ratio (SSR) & Harus $\geq 0,7$ & 0,857 & Fit Model \\
\hline
\end{tabular}

Tabel 4. Hasil Evaluasi Jalur

\begin{tabular}{lccc}
\hline \multicolumn{1}{c}{ Path } & Direct effect & \multirow{2}{*}{ Kesimpulan } \\
\cline { 2 - 3 } & Koefisien & P-Value & Ditolak \\
\hline Debt to Equity -> Dividend Payout Ratio & $-0,111$ & 0,090 & Diterima \\
Total Asset Turn Over -> Dividend Payout Ratio & 0,138 & 0,046 & Diterima \\
Ln_Total Asset -> Dividend Payout Ratio & 0,175 & 0,016 & Ditolak \\
Debt to Equity -> Ln_Harga Saham & $-0,250$ & 0,001 & Diterima \\
Total Asset Turn Over -> Ln_Harga Saham & 0,353 & $<0,001$ & Diterima \\
Ln_Total Aset -> Ln_Harga Saham & 0,559 & $<0,001$ & Diterima \\
Divident Payout Ratio -> Ln_Harga Saham & 0,151 & 0,033 & \\
\hline
\end{tabular}


(significance level $=1 \%)$ (Ghozali \& Latan, 2014). Penelitian ini mengunakan P-value 0,05 (significance level $=5 \%$ ). Hasil evaluasi jalur disajikan pada Tabel 4.

Berdasarkan Tabel 4, hasil evaluasi jalur terdapat 5 jalur yang terbukti memiliki hubungan yang mempunyai pengaruh positif antar variabel, yaitu hubungan total asset turn over terhadap dividend payout ratio, hubungan Ln_total asset terhadap dividend payout ratio, hubungan total asset turn over terhadap Ln_harga saham, hubungan Ln_total asset terhadap Ln_harga saham, dan hubungan dividend payout ratio terhadap Ln_harga saham. Sedangkan 2 jalur terbukti memiliki hubungan pengaruh negatif antar variabel yaitu hubungan debt to equity terhadap dividend payout ratio dan hubungan debt to equity terhadap Ln_harga saham.

Hasil pengujian efek mediasi dalam program WarpPLS dapat dilihat dari hasil outputview indirect dan total effects. Nilai signifikan yang digunakan untuk menilai hubungan mediasi dengan melihat nilai P-value 0,10 (significance level= 10\%), 0,05 (significance level $=5 \%$ ), dan 0,01 (significance level $=1 \%$ ) (Ghozali \& Latan, 2014). Penelitian ini mengunakan P-value 0,05 (significance level= 5\%). Efek mediasi dapat dilakukan dengan melihat P-value berdasarkan model mediasi yang dibangun dalam penelitian ini, yaitu hubungan debt to equity ratio, total assets turn over, dan Ln_total asset terhadap Ln_harga saham yang dimediasi oleh dividend payout ratio. Hasil evaluasi jalur mediasi disajikan pada Tabel 5.

Merujuk hasil Tabel 5, secara keseluruhan dapat disimpulkan bahwa variabel dividend payout ratio tidak terbukti sebagai variabel mediasi hubungan debt to equity, total asset turn over, dan Ln_total asset terhadap Ln_harga saham.

\section{PEMBAHASAN}

\section{Pengaruh Rasio Leverage Perusahaan terhadap Kebijakan Dividen}

Hasil uji terhadap hipotesis 1, yaitu rasio leverage perusahaan berpengaruh negatif terhadap kebijakan dividen, hasilnya menunjukkan pengaruh debt to equity terhadap dividend payout ratio memiliki nilai sebesar $-0,111$ dengan nilai P-values $0,090 \geq 0,05$. Dengan demikian hipotesis pertama $\left(\mathrm{H}_{1}\right)$ ditolak. Hasil penelitian ini tidak sesuai dengan penelitian yang terdahulu dilakukan oleh Sumiadji (2011), Emamalizadeh, Ahmadi, \& Pouyamanesh (2013), dan Awad (2015), dimana hasilnya menunjukkan bahwa rasio leverage perusahaan berpengaruh positif terhadap kebijakan dividen. Hubungan logis yang dapat dikemukakan bahwa perusahaan yang memiliki struktur permodalan utang yang tinggi akan memprioritaskan melunasi kewajiban terlebih dahulu sebelum membagikan dividen.

\section{Pengaruh Rasio Aktivitas Perusahaan terhadap Kebijakan Dividen}

Hasil uji terhadap hipotesis kedua $\left(\mathrm{H}_{2}\right)$, yaitu rasio aktivitas perusahaan berpengaruh positif terhadap kebijakan dividen, hasilnya menunjukkan besarnya pengaruh total asset turn over terhadap

Tabel 5. Hasil Evaluasi Jalur Mediasi

\begin{tabular}{lccc}
\hline \multicolumn{1}{c}{ Jalur Mediasi } & \multicolumn{2}{c}{ Effect for with 2 Segments } & \multirow{2}{*}{ Kesimpulan } \\
\cline { 2 - 4 } $\begin{array}{l}\text { Hubungan debt to equity terhadap Ln_harga saham yang } \\
\text { dimediasi oleh dividend payout ratio }\end{array}$ & $-0,017$ & 0,389 & Ditolak \\
$\begin{array}{l}\text { Hubungan total asset turn over terhadap Ln_harga saham yang } \\
\text { dimediasi oleh dividend payout ratio }\end{array}$ & 0,021 & 0,363 & Ditolak \\
$\begin{array}{l}\text { Hubungan Ln_total asset terhadap Ln_harga saham yang } \\
\text { dimediasi oleh dividend payout ratio }\end{array}$ & 0,026 & 0,328 & Ditolak \\
\hline
\end{tabular}




\section{Jurnal Keuangan dan Perbankan | KEUANGAN}

Vol. 21, No. 3, Juli 2017: 459-472

dividend payout ratio memiliki nilai sebesar 0,138 dengan nilai P-values $0,046 \leq 0,05$. Dengan demikian hipotesis kedua $\left(\mathrm{H}_{2}\right)$ diterima. Hal ini sesuai dengan penelitian yang dilakukan oleh Rahmawati et al. (2014) serta Hanim, Dzulkirom, \& Topowijono (2015) dimana hasilnya menyatakan bahwa total asset turn over perusahaan berpengaruh positif terhadap dividend payout ratio. Hubungan logis yang dapat dikemukakan bahwa perusahaan dengan rasio aktivitas yang tinggi dapat memberikan signal kepada calon investor bahwa perusahaan dalam kondisi baik, serta kemungkinan perusahaan akan memberikan dividen kepada para pemegang saham.

\section{Pengaruh Ukuran Perusahaan terhadap Kebijakan Dividen}

Hasil uji terhadap hipotesis ketiga $\left(\mathrm{H}_{3}\right)$, yaitu perusahaan berpengaruh positif terhadap kebijakan dividen. Hasilnya menunjukkan besarnya pengaruh Ln_total asset terhadap dividend payout ratio memiliki nilai sebesar 0,175 dengan nilai $\mathrm{P}$ values $0,016 \leq 0,05$. Dengan demikian hipotesis ketiga $\left(\mathrm{H}_{3}\right)$ diterima. Hasil ini sesuai dengan penelitian yang dilakukan oleh Kardianah \& Soedjono (2013) serta Khan et al. (2013), dimana hasilnya menunjukkan bahwa ukuran perusahaan berpengaruh positif terhadap kebijakan dividen. Hubungan logis yang dapat dikemukakan bahwa perusahaan dengan total aset yang besar dapat memberikan signal kepada calon investor bahwa perusahaan dalam kondisi baik dan dalam keadaan yang sehat serta kemungkinan perusahaan akan memberikan dividen kepada para pemegang saham.

\section{Pengaruh Rasio Leverage terhadap Harga Saham}

Hasil uji terhadap hipotesis keempat $\left(\mathrm{H}_{4}\right)$ yaitu rasio leverage perusahaan berpengaruh negatif terhadap harga saham, menunjukkan besarnya pengaruh debt to equity terhadap Ln_harga saham memiliki nilai sebesar - 0,250 dengan nilai P-values $0,001 \mathrm{~d}^{\prime \prime} 0,05$. Dengan demikian hipotesis keempat $\left(\mathrm{H}_{4}\right)$ ditolak. Hal ini tidak sesuai dengan penelitian yang dilakukan oleh Kohansal et al. (2013) serta Ullah \& Shah (2014), dimana hasilnya menunjukkan bahwa leverage perusahaan berpengaruh positif terhadap harga saham. Hubungan logis yang dapat dikemukakan bahwa perusahaan yang memiliki struktur permodalan berasal dari hutang yang tinggi akan berdampak kepada calon investor, dimana calon investor dan investor akan berpaling atau lebih memilih perusahaan dengan tingkat leverage yang rendah disebabkan calon investor dan investor akan memilih perusahaan dengan tingkat risiko yang rendah.

\section{Pengaruh Rasio Aktivitas terhadap Harga Saham}

Hasil uji terhadap hipotesis kelima $\left(\mathrm{H}_{5}\right)$ yaitu rasio aktivitas perusahaan berpengaruh positif terhadap harga saham, hasilnya menunjukkan besarnya pengaruh total asset turn over terhadap Ln_harga saham memiliki nilai sebesar 0,353 dengan nilai $\mathrm{P}$ values $0,000 \leq 0,05$. Dengan demikian hipotesis kelima $\left(\mathrm{H}_{5}\right)$ diterima. Terbukti hasilnya sama dengan penelitian yang dilakukan oleh Martani, Mulyono, \& Khairurizka (2009) serta Khotimah \& Murtaqi (2015), dimana hasilnya menunjukkan bahwa rasio aktivitas perusahaan berpengaruh positif terhadap harga saham. Hubungan logis yang dapat dikemukakan perusahaan dengan rasio aktivitas yang tinggi dapat memberikan signal kepada calon investor bahwa perusahaan dalam kondisi baik, serta akan berdampak langsung terhadap peningkatan harga saham.

\section{Pengaruh Ukuran Perusahaan terhadap Harga Saham}

Hasil uji terhadap hipotesis keenam $\left(\mathrm{H}_{6}\right)$, yaitu ukuran perusahaan berpengaruh positif terhadap harga saham, hasilnya menunjukkan besar- 
nya pengaruh Ln_total asset terhadap Ln_harga saham yang memiliki nilai sebesar 0,559 dengan nilai P-values $0,000 \leq 0,05$. Dengan demikian hipotesis keenam $\left(\mathrm{H}_{6}\right)$ diterima. Hal ini sesuai dengan penelitian yang dilakukan oleh Acheampong, Agalega, \& Shibu (2014) serta Murniati (2016), dimana hasilnya menemukan bahwa ukuran perusahaan berpengaruh positif terhadap harga saham. Hubungan logis yang dapat dikemukakan bahwa ukuran perusahaan yang dilihat dari sisi besarnya total asset yang dimiliki oleh perusahaan akan dapat memberikan signal kepada investor dan calon investor bahwa perusahaan dalam kondisi baik, serta menjadikan reputasi yang baik, secara otomatis akan memberikan signal yang baik terhadap peningkatan harga saham.

\section{Pengaruh Kebijakan Dividen terhadap Harga Saham}

Hasil uji terhadap hipotesis ketujuh $\left(\mathrm{H}_{7}\right)$, yaitu kebijakan dividen perusahaan berpengaruh positif terhadap harga saham, hasilnya menunjukkan besarnya pengaruh dividend payout ratio terhadap Ln_harga saham dimana memiliki nilai sebesar 0,151 dengan nilai $\mathrm{P}$ values $0,033 \mathrm{~d}$ " 0,05. Dengan demikian hipotesis ketujuh $\left(\mathrm{H}_{7}\right)$ diterima. Hal ini sesuai dengan penelitian yang dilakukan oleh Hasan, Uzzaman, \& Karim (2013), Hunjra et al. (2014), Menike \& Prabath (2014), serta Ullah, Saqib, \& Usman (2015) yang menyatakan bahwa kebijakan dividen berpengaruh positif terhadap harga saham. Hubungan yang logis yang dapat dikemukakan bahwa dengan pemberian dividen kepada pemegang saham akan mencerminkan kinerja perusahaan dalam kondisi baik, kondisi seperti ini yang diminati investor dan calon investor untuk membeli saham perusahaan tersebut.

\section{Hasil Uji Efek Mediasi}

Hasil uji mediasi, yaitu kebijakan dividen tidak memediasi hubungan pengaruh rasio lever- age, rasio aktivitas, dan ukuran perusahaan terhadap harga saham. Berdasarkan Tabel 3 yang memiliki nilai indirect effect dan memiliki nilai P-value di bawah 0,05 . Artinya dividend payout ratio tidak memediasi debt to equity, total asset turn over, dan Ln_harga saham terhadap Ln_harga saham. Dengan demikian hipotesis kedelapan $\left(\mathrm{H}_{8}\right)$ ditolak.

Hubungan yang logis hutang perusahaan pada dasarnya digunakan untuk investasi, atau membayar hutang perusahaan, serta dengan pemberian dividen kepada pemegang saham akan memcerminkan bahwa kinerja perusahaan dalam kondisi baik, namun tidak berdampak dalam peningkatan harga saham. Hal ini sesuai dengan irrelevance theory dimana teori yang menyatakan bahwa kebijakan dividen tidak mempunyai pengaruh baik terhadap nilai perusahaan maupun terhadap biaya modalnya. Menurut teori ini, kebijakan dividen tidak memengaruhi harga saham, dimana teori menyatakan bahwa pada dasarnya nilai suatu perusahaan ditentukan tersendiri oleh kemampuan aset perusahaan untuk menghasilkan laba atau kebijakan investasi (Miller \& Modigliani, 1961).

\section{SIMPULAN DAN SARAN}

\section{Simpulan}

Berdasarkan hasil pengujian, dapat disimpulkan total asset turn over dan ukuran perusahaan berpengaruh positif terhadap kebijakan dividen, sedangkan debt to equity berpengaruh negatif terhadap dividen. Dengan demikian hal ini menunjukkan bahwa semakin tinggi aktivitas perusahaan dan besarnya ukuran suatu perusahaan, maka semakin besar peluang perusahaan akan memberikan dividen kepada pihak pemegang saham. Selain itu hasil penelitian ini membuktikan bahwa total asset turn over, ukuran perusahaan, dan dividend payout ratio berpengaruh positif terhadap harga saham. Sedang debt to equity berpengaruh negatif terhadap harga saham. Variabel leverage yang diukur dengan debt to equity dalam penelitian ini bukanlah predi- 


\section{Jurnal Keuangan dan Perbankan | KEUANGAN}

Vol. 21, No. 3, Juli 2017: 459-472

ktor yang baik yang harus dipertimbangan oleh investor dalam menentukan harga saham.

\section{Saran}

Atas dasar simpulan serta keterbatasan penelitian yang ada, terdapat beberapa saran agar penelitian mendatang bisa lebih sempurna, antara lain: (1) penelitian selanjutnya dapat menggunakan data rasio yang lain seperti rasio likuiditas, rasio profitabilitas, rasio nilai perusahaan, pertumbuhan perusahaan, penerapan good corporate governance, serta periode yang lebih panjang lagi sehingga dapat meningkatkan kualitas penelitian; dan (2) penelitian berikutnya dapat menambahkan model analisis yang lebih kompleks seperti menggunakan variabel moderasi serta menggunakan variabel kontrol, sehingga tingkat signifikansinya akan lebih baik. Sedapat mungkin dilakukan sinkronisasi mengenai data dividen, data harga saham, dan data rasio keuangan, atau menambah uji beda sebelum dan sesudah pengumuman dividen dan pengaruhnya terhadap harga saham.

\section{DAFTAR PUSTAKA}

Abdullah, M.N., Parvez, K., Karim, T., \& Tooheen, R.B. 2015. The Impact of Financial Leverage and Market Size on Stock Returns on the Dhaka Stock Exchange: Evidence from Selected Stocks in the Manufacturing Sector. International Journal of Economics, Finance, and Management Sciences, 3(1): 1015.

Acheampong, P., Agalega, E., \& Shibu, A.K. 2014. The Effect of Financial Leverage and Market Size on Stock Returns on the Ghana Stock Exchange: Evidence from Selected Stocks in the Manufacturing Sector. International Journal of Financial Research, 5(1): 125-134.

Al-Tamimi, H.A.H. \& Kalli, A.A.B. 2009. Financial Literacy and Investment Decisions of UAE Investors. The Journal of Risk Finance, 10(5): 500-516.

Anthony, R.N. \& Govindarajan, V. 2005. Management Control Systems. Jakarta: Salemba Empat.
Asif, A., Rasool, W., \& Kamal, Y. 2011. Impact of Financial Leverage on Dividend Policy: Empirical Evidence from Karachi Stock Exchange-listed Companies. African Journal of Business Management, 5(4): 1312-1324.

Awad, B. 2015. Determinants of Dividend Policy in Kuwait Stock Exchange. International Journal of Business and Management Review. 3(7): 72-78.

Black, F. 1976. The Dividen Puzzle. Journal of Portofolio Management, 2(2): 215-220.

Darmadji E Fakhruddin. 2011. Pasar Modal di Indonesia. Edisi Ketiga. Salemba Empat: Jakarta.

Dewi, S.C. 2008. Pengaruh Kepemilikan Managerial, Kepemilikan Institusional, Kebijakan Hutang, Profitabilitas, dan Ukuran Perusahaan terhadap Kebijakan Dividen. Jurnal Bisnis dan Akuntansi, 10(1): 47-58.

Emamalizadeh, M., Ahmadi, M., \& Pouyamanesh, J. 2013. Impact of Financial Leverage on Dividend Policy at Tehran Stock Exchange: A Case Study of Food Industry. African Journal of Business Management, 7(34): 3287-3296.

Fahmi, I. 2012. Analisis Laporan Keuangan. Cetakan Kedua. Bandung: Alfabeta.

Ginting, S. \& Suriany. Analisis Faktor-Faktor yang Mempengaruhi Harga Saham pada Perusahaan Manufaktur di Bursa Efek Indonesia. Jurnal Wira Ekonomi Mikroskil, 3(2): 61-70.

Ghozali, I. \& Latan, H. 2014. Partial Least Squares Konsep, Metode dan Aplikasi Menggunakan Program WarpPLS 4.0. Semarang: Badan Penerbit UNDIP.

Gunarso, P. 2014. Laba Akuntansi, Leverage, dan Ukuran Perusahaan terhadap Harga Saham di Bursa Efek Indonesia. Jurnal Keuangan dan Perbankan, 16(1): 63-71.

Gordon, M.J. 1959. Dividends, Earnings, and Stock Prices. The Review of Economics and Statistics, 41(2): 99-105

Hadi, N. 2015. Pasar Modal. Yogyakarta: Graha Ilmu.

Hanim, S., Dzulkirom, M.A.R., \& Topowijono. 2015. Analisis Fundamental Saham Syariah dan Saham Kovensional terhadap Kebijakan Pembayaran Dividen (Studi pada Perusahaan Manufaktur yang Terdaftar di JII dan LQ45 Periode 2010-2013). Jurnal Administrasi Bisnis (JAB), 2(2): 1-10. 
Hartono, J. 2008. Teori Portofolio dan Analisis Investasi. Yogyakarta: BPFE.

Harmono. 2011. Manajemen Keuangan Berbasis Balanced Scorecard Pendekatan Teori, Kasus, dan Riset Bisnis. Jakarta: Bumi Aksara.

Hasan, Md., Uzzaman, A.Md., \& Karim, R.A. 2013. The Effect of Dividend Policy on Share Price: An Evaluative Study. IOSR Journal of Economics and Finance, 1(4): 06-11.

Hunjra, A.I., Shahza, M., Chani, M.I., Ul-Hassan, S., \& Mustafa, U. 2014. Impact of Dividend Policy, Earning per Share, Return on Equity, Profit after Tax on Stock Prices. International Journal of Economics and Empirical Research, 2(3): 109-115.

Istanti, S.L.W. 2013. Pengaruh Kebijakan Dividen terhadap Harga Saham pada Perusahaan LQ45. Potensia, 19(1).

Jensen, M.C. \& Meckling, W.H. 1976. Theory of The Firm: Managerial Behavior, Agency Costs, and Ownership Structure. Journal of Financial Economics, 3(4): 305-360.

Kadir, A. 2010. Analisis Faktor-faktor yang Memengaruhi Kebijakan Dividen pada Perusahaan Credit Agencies Go Public di Bursa Efek Indonesia. Jurnal Manajemen dan Akuntansi, 11(1): 10-20.

Kasmir. 2011. Analisis Laporan Keuangan. Jakarta: Rajawali Pers.

Kardianah \& Soedjono. 2013. Pengaruh Kepemilikan Institusional, Kebijakan Utang, Ukuran Perusahaan, Profitabilitas, dan Likuiditas terhadap Kebijakan Dividen. Jurnal Ilmu $\mathcal{E}$ Riset Manajemen, 2(1): 1-21.

Keown, A.J., Scott, D.F., Martin, J.D., \& Petty, J.W. 2008. Dasar-Dasar Manajemen Keuangan. Jakarta: Salemba Empat.

Khan, W., Naz, A., Khan, Q., Khan, T., \& Mughal, I. 2013. Impact Assessment of Financial Performance and Leverage on Dividend Policy of Pakistan Chemical and Pharmaceutical Industries. Middle-East Journal of Scientific Research, 16(10): 1376-1382.

Khotimah, K. \& Murtaqi, I. 2015. The Fundamental Analysis of Indonesian Stock Return Case Study: Listed Public Companies in Sub Sector Food and Beverage for the Period 2003-2013). Journal of Business and Management, 4(1): 95-104.
Kohansal, M.R., Dadrasmoghadam, A., Karmozdi, K.M., \& Mohseni, A. 2013. Relationship between Financial Ratios and Stock Prices for the Food Industry Firms in Stock Exchange of Iran. World Applied Programming, 3(10): 512-521.

Martani, D., Mulyono, \& Khairurizka, R. 2009. The Effect of Financial Ratios, Firm Size, and Cash Flow From Operating Activities in the interim Report to the Stock Return. Chinese Business Review, 8(6): 44-55.

Menike, M.G.P.D. \& Prabath, U.S. 2014. The Impact of Accounting Variables on Stock Price: Evidence from the Colombo Stock Exchange, Sri Lanka. International Journal of Business and Management, 9(5): 125-137.

Miller, M.H. \& Modigliani, F. 1961. Dividend Policy, Growth, and the Valuation of Shares. The Journal of Business, 34(4): 411-433.

Murniati, S. 2016. Effect of Capital Structure, Company Size, and Profitability on the Stock Price of Food and Beverage Companies Listed on the Indonesia Stock Exchange. Information Management and Business Review, 8(1): 23-29.

Mulyadi. 2010. Akuntansi Manajemen. Edisi Ketiga. Jakarta: Salemba Empat.

Panjaitan, Y., Dewinta, O., \& Desinta, K.S. 2004. Analisis Harga Saham, Ukuran Perusahaan dan Risiko terhadap Return yang Diharapkan Investor pada Perusahaan-perusahaan Saham Aktif. Balance, 1(1): 56-72.

Prawira, I.Y., Dzulkirom, M.A.R., \& Endang, M.G.W.N.P. 2014. Pengaruh Leverage, Likuiditas, Profitabilitas, dan Ukuran Perusahaan terhadap Kebijakan Dividen (Studi pada Perusahaan Perbankan yang Terdaftar di Bursa Efek Indonesia Tahun 20102013). Jurnal Administrasi Bisnis (JAB), 15(1): 1-7.

Radoni, A. \& Ali, H. 2014. Manajemen Keuangan Modern. Jakarta: Mitra Kencana.

Rahmawati, N.D., Saerang, I.S., \& Rate, P.V. 2014. Kinerja Keuangan Pengaruhnya terhadap Kebijakan Dividen pada Perusahaan BUMN di Bursa Efek Indonesia. Jurnal EMBA, 2(2): 1306-1317.

Rakasetya, G.G., Darminto, \& Dzulkirom M.A.R. 2013. Pengaruh Faktor Mikro dan Faktor Makro Ekonomi terhadap Harga Saham Perusahaan Mining and Mining Services yang terdaftar di 


\section{Jurnal Keuangan dan Perbankan | KEUANGAN}

Vol. 21, No. 3, Juli 2017: 459-472

Bursa Efek Indonesia (BEI) Periode 2008-2011. Jurnal Administrasi Bisnis (JAB), 6(2): 1-12.

Rahmandia, F. 2013. Faktor-faktor yang Memengaruhi Harga Saham Perusahaan di Sektor Industri Barang Konsumsi yang Terdaf'tar di BEI Periode 2007-2011. Jurnal Mahasiswa Universitas Surabaya, 2(1): 1-21.

Riyanto, B. 2011. Dasar-Dasar Pembelajaran Perusahaan. Yogyakarta: BPFE.

Ross, S.A. 1977. The Determination of Financial Structure: The Incentive Signalling Approach. The Bell Journal of Economics, 8(1): 23-40.

Saptadi, A. 2007. Pengaruh Return on Investment (ROI), Price Earning Ratio (PER), dan Earning per Share (EPS) terhadap Harga Saham pada Perusahaan Manufaktur yang Terdaftar di Bursa Efek Jakarta. Skripsi. Universitas Negeri Semarang.

Sumiadji. 2011. Analisis Variabel Keuangan yang Memengaruhi Kebijakan Dividen. Jurnal Dinamika Akuntansi, 3(2): 129-138.

Sutrisno. 2009. Manajemen Keuangan Teori, Konsep, dan Aplikasi. Yogyakarta: Ekonisia.
Syamsuddin, L. 2009. Manajemen Keuangan Perusahaan. Cetakan Ketujuh. Jakarta: Rajawali Pers.

Tandelilin, E. 2010. Portofolio dan Investasi: Teori dan Aplikasi. Yogyakarta: Kanisius.

Tan, S. \& Syarif, A. 2014. Analisis Faktor-Faktor yang Memengaruhi Harga Saham pada Industri Transportation Services di Bursa Efek Indonesia Tahun 2009-2012. Jurnal Dinamika Manajemen, 2(2): 116129.

Ullah, I. \& Shah, A. 2014. The Effect of Capital Structure on Abnormal Stock Returns: Evidence from Pakistan. Business \& Economic Review, 6(1): 1-18.

Ullah, H., Saqib, S.E., \& Usman, H. 2015. The Impact of Dividend Policy on Stock Price Volatility: A Case Study of Selected Firms from Textile Industry in Pakistan. International Journal of Academic Research in Economics and Management Sciences, 4(3): 40-51. 